\title{
Digestion and Moral Progress in Epictetus
}

Michael Tremblay

The Stoic Epictetus famously criticizes his students for studying Stoicism as 'mere theory' and encouraged them to add training to their educational program. This is made all the more interesting by the fact that Epictetus, as a Stoic, was committed to notion that wisdom is sufficient to be virtuous, so theory should be all that's required to achieve virtue. How are we then to make sense of Epictetus criticism of an overreliance on theory, and his insistence on adding training? This paper argues that this tension can be resolved through an appeal to the metaphor of 'digesting theory'. Epictetus discusses the digestion of theory in three parts of his existent work. While the use of digestion as a metaphor for moral progress in Epictetus has been noted, an explanation as to exactly what this process consists of has yet to be provided. This paper attempts to provide such an account. I argue that digestion consists of assimilating what we have learnt conceptually, at the level of general principles, into specific beliefs concerning existent objects. I argue further that this process of digestion can only be achieved through what Epictetus calls training (askesis).

The following paper will examine the metaphor of digestion (pepsis) in the work of Epictetus. ${ }^{1}$ While the use of digestion as a metaphor for moral progress in Epictetus has been noted and in partially explored in recent literature ${ }^{2}$, an explanation as to exactly what this essential process consists of has yet to be provided.

The aim of the paper is two-fold. First, it attempts to elucidate what exactly the process of digestion entails for Epictetus' moral psychology, and second it will examine in what way digestion fits within his greater pedagogical system. The hope is that this explanation will lend credence to the claim, put forward by Sellars ${ }^{3}$, that Epictetus' educational program is divided into

\footnotetext{
${ }^{1}$ A previous version of this paper was presented at the 2018 Philosofest at the University of Ottawa, as well as the 2019 meeting of the Hellenistic Philosophy Society at the Pacific APA. I am grateful for those present for the comments. Additionally I would like to thank Annie Larivée for her helpful comments on an earlier version of this paper.

${ }^{2}$ Sharpe (2012), Sellars (2007)

${ }^{3} 2007$.
} 
two complimentary components: the instruction of rational principles (logoi) and training (askesis).

\section{Introduction}

Pioneered by the influential work of $\mathrm{Hadot}^{4}$, there has been a resurgence of interest in examining whether ancient philosophy should be understood as a more than a system of theories, but also as a way of life. It is becoming increasingly popular to view ancient philosophy as an art or craft (techne) that was not just studied, but also practiced..$^{5}$ When searching for ancient illustrations of those who conceived of philosophy as a craft, the Stoic Epictetus serves as an often referenced example. He was a teacher who demanded his students not just study philosophy, but to embody it, and to demonstrate the progress they have made through their actions. ${ }^{6}$ He also criticized those who turned to Sophistry or teaching without having learnt to live by what they teach. $^{7}$

While it is clear that Epictetus demanded his students live as Stoics, and reflect this in their actions, it remains controversial as to how they were best to go about doing so. As such, once again inspired by the work of Hadot, focus has turned to the educational program of Epictetus. Roughly speaking, interest in this aspect of Epictetus often concerns the following question:

(1) Did Epictetus believe training in 'spiritual exercises' were required to achieve moral progress, or did he believe the study of theory alone to be sufficient? ${ }^{8}$

For those that believe training is necessary for Epictetus, there are two additional questions:

\footnotetext{
${ }^{4}$ Philosophy as a Way of Life: Spiritual Exercises from Socrates to Foucault. Trans. Arnold I. Davidson. Malden, MA: Blackwell, 1995; The Inner Citadel: the "Meditations" of Marcus Aurelius. Trans. Michael Chase. Cambridge, Mass.: Harvard University Press, 1998.

${ }^{5}$ Cf. M. Nussbaum, The Therapy of Desire: Theory and Practice in Hellenistic Ethics. Princeton, N.J: Princeton University Press, 1994; Sellars (2004); J. M. Cooper Pursuits of Wisdom: Six Ways of Life in Ancient Philosophy from Socrates to Plotinus. Princeton University Press, 2012.

${ }^{6}$ Disc. I 4 5-13

${ }^{7}$ Disc. III 21.

${ }^{8}$ Cf. Cooper (2007) argues that rational argument is sufficient for moral improvement in Epictetus, whereas Sellars (2007) and Sharpe (2012) argue that training, in conjunction with theory, is necessary.
} 
(2) What is the function of training for Epictetus? ${ }^{9}$

(3) How can the necessity of this training possibly fit within Epictetus' psychology, when the Stoics are committed a wholly rational self? ${ }^{10}$

This paper will primarily address the second question by exploring the metaphor of digestion. Digestion, this paper will argue, is one of the primary goals of training in Epictetus. It will bracket the first question, taking it to be true, for reasons to be discussed shortly, that the educational program of Epictetus requires both theory and training. The third question, while interesting and worthy of development, falls outside the scope of this paper. The hope is that through focusing on the function of training in Epictetus, this paper will both provide new insight into the pedagogical system of Epictetus, as well as provide evidence for those still undecided that training is in fact a necessary component of philosophy for Epictetus. However, before the function of training can be discussed properly, we must begin with a foundational understanding of theory and training in Epictetus.

\section{Theory and Training}

In his paper Stoic Practical Philosophy in the Imperial Period (2007), Sellars argues that there is a tradition, beginning with Socrates, to view perfecting any craft (tekhne) as requiring both theory (logos) and training (askesis). ${ }^{11}$ The apprentice craftsman must understand how to make a shoe, as well as the final ends of shoe-making, but these alone are insufficient without also developing the technical skill-set required to put this theory into practice. Sellars argues that this conception of tekhne is present in Epictetus, who views philosophy as a way of life, or an art to be

\footnotetext{
${ }^{9}$ Cf. Hadot (1998, 82-98), Braicovich (2012) for major discussions, also Sellars (2007, 135-8) and Sharpe (2012, 380-5).

${ }^{10}$ The reason this question is substantial is that it seems if rational discourse and the studying of philosophy are not sufficient for moral progress, then the intellectualism of Epictetus is undermined. One would assume that a wholly rational self would not need to be trained like the irrational part of the soul found in Plato. This problem is noted by Brennan (2003, 278-9) and Johnson (2014, Page 83, Footnote 30). Braicovitch (2012) attempts to show that at least one exercise, repetition, can be coherent with Epictetus' philosophy if we understand its role properly.

${ }^{11}$ It is important to note that while Sellars admits his indebtedness to Hadot's work on spiritual exercises in Ancient philosophy, this conception differs from that of Hadot. Hadot views Ancient philosophy as a spiritual exercise, where-as Sellars is proposing that exercises from one part of a two-part program, of which theory makes up the other half (Sellars, 2007, ft. 2)
} 
practiced. This should not be too surprising, given Epictetus' well-referenced idealization of Socrates. $^{12}$

If Sellars is correct, then there exists a division in the philosophy of Epictetus, between the study of theory and training. Both are necessary to perfect the craft of living well, and neither is sufficient on its own. When we examine the Discourses, there seems to be strong textual evidence for such an interpretation. ${ }^{13}$ Additionally, it becomes apparent that there is a specific order with which these two parts must be engaged. In order to live well we begin with theory, for, due to its abstracted nature, it is easier to master first and provides a proper foundation for the more difficult training:

The philosophers, therefore, first exercise us in theory, which is the easier task, and then lead us to the more difficult: for in theory there is nothing to oppose our following what we are taught; but in life there are many things to distract us. ${ }^{14}$

However theory alone is insufficient to live well, because living well extends beyond the domain of theory, ${ }^{15}$ thus we complement our theory with training:

For this reason philosophers exhort us not to be contented with mere learning, but to add practice also, and then training. ${ }^{16}$

Theory and training rely upon each other then. When studying theory, we learn the principles and precepts of Epictetus' brand of Stoicism. This would include, among other things, instruction in the nature of virtue, the divinity of the universe, and what is in our control and what is not. ${ }^{17}$ However, Epictetus criticized those who focused exclusively on theory, and ignored its implementation and practice. ${ }^{18}$ Theory is inert and valueless unless we practice and train through exercises. Thus Sellars concludes that "the purpose of these exercises is to enable one to express

\footnotetext{
${ }^{12}$ Cf. Long 2002, 67-96 for a good overview of how Epictetus' philosophy is heavily influenced by the figure of Socrates.

${ }^{13} \mathrm{Cf}$. III 23 1-3 in which Epictetus discusses how a craftsman or athlete is useless without both the skill to implement the task, and the knowledge of what their task is.

${ }^{14}$ I 263 trans. Hard.

15 "For is not reading a kind of preparation for living, but living itself made up of things other than books?" Disc. IV 411.

${ }^{16}$ II 913 trans. Hard

${ }^{17}$ Cf. I 1.

${ }^{18}$ Cf. I 4 6-17.
} 
one's philosophical principles in one's actions, thereby transforming one's way of life". ${ }^{19}$ By no means does this understanding of Epictetus imply that he did not conceive of rational instruction as essential for living well. ${ }^{20}$ Theory is the necessary first part in a two-part process. Nonetheless, the value of theory cannot be actualized unless we train ourselves.

So if the purpose of training is to allow the individual to embody and live by their lessons, what is its function on a psychological level? How does it achieve this purpose? Epictetus is notoriously committed to a Socratic intellectualism, in which he holds that we must assent to that which seems true. ${ }^{21}$ It seems strange then, given this understanding of our psychology, that Epictetus does not believe we could achieve proper behavior through coming to understand the logical necessity of Stoic philosophical doctrine. The most important question then is, for someone committed to Socratic intellectualism like Epictetus, what does training do that the studying of theory could not? The remainder of this paper shall argue that what training does is allow for the digestion of theory.

When discussing the function of training, both Sellars ${ }^{22}$ and Sharpe ${ }^{23}$ note the metaphor of digestion (pepsis) as the one utilized by Epictetus to account for the function of training. However, in-depth explanations as to what digestion entails are not provided. Sharpe provides no explanation as to what is meant by digestion. Sellars claims that for Epictetus, to digest theory is "to absorb one's philosophical ideas into one's character" 24 . This is a helpful starting point, but such an account leaves much room for an improved understanding of the function of digestion. My aim is to provide such an account.

\footnotetext{
${ }^{19} 2007,132$.

${ }^{20}$ Cf. Cooper (2007) for a good explanation of why theory is necessary for moral improvement for Epictetus, despite Epictetus' tendency to criticize those who focus too heavily upon study.

${ }^{21}$ Cf. I 28 1-5; 33 2-4. Also Long (2002, 98-100). Long refers to this as Epictetus' "optimistic rationalism". $222007,132$.

$232012,379$.

${ }^{24} 2007,133$.
} 


\section{Textual Evidence}

Epictetus refers to the phenomenon of digestion (pepsis) three times within the Discourses and Enchiridion. ${ }^{25}$ In addition to this, there is one further passage in which he discusses the interrelated phenomenon of vomiting (emesis). ${ }^{26}$ Reference to digestion first appears in Book 2 Chapter 9 of the Discourses. It is introduced as an explanation for why students are able to act in opposition to the Stoic theory they know so well. Epictetus explains that each student present before him is able to provide a systematic discourse on the nature of good and evil. Yet, if someone was to laugh at them during this, they would each become flustered, despite their just explaining that this laughter would qualify as indifferent. ${ }^{27}$ The reason for this bizarre disparity between talk and action, Epictetus explains, is a lack of digestion:

It is one thing to hoard up bread and wine in a store-cupboard, and another to eat it. What is eaten is digested, distributed and becomes nerves, flesh, bones, blood, a fine complexion, ease of breathing. Whatever is hoarded up is ready, indeed, whenever you have a mind to show it; but no further use to you than the mere reputation that you have for possessing it. ${ }^{28}$

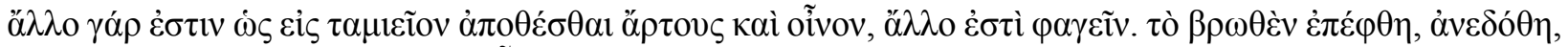

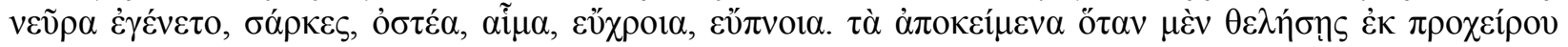

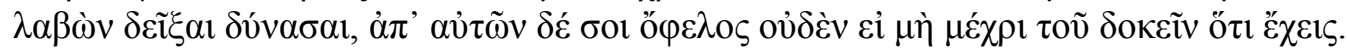

Epictetus goes on to explain that those who have not digested their theory are like early Christians who have been baptized, but do not change their way of living. They take on title of philosopher in name only. These kinds of students pride themselves in knowing the philosophical principles of Stoicism, but do not act in accordance with them.

In this first passage, we see that digestion is the bridge or connection between studying theory, and being able to act in accordance with that theory. In other words, digestion allows one to progress from understanding the nature good, evil and indifferent objects, to living in line with that understanding. Philosophical principles are not manifested in our actions until they have been digested. Digestion then, seems a necessary process to actualize the value of studied theory. Theory, like stored food, is morally inert and valueless without being digested. Its sole 'value',

\footnotetext{
${ }^{25}$ Disc. II 9 13-22; III 21 1-6; Ench. 46.

${ }^{26}$ Disc. I 26 15-18.

${ }^{27}$ Disc. I 9 15-17.

${ }^{28}$ Disc, II 918 trans. Hard.
} 
pre-digestion, is the reputation it confers, something Epictetus would not consider to actually be a good at all. ${ }^{29}$ This same idea, that digestion is the connection between theory and proper action, is emphasized again in a later passage:

Those who have learned precepts $(\theta \varepsilon \omega \rho \eta \dot{\mu} \mu \alpha \tau)$ as mere theory want to vomit them up immediately, just as people with weak stomachs do with their food. Digest your precepts first, and you will not vomit them up in this way; otherwise they really do turn to vomit, tainted matter unfit to eat. Then show us some change that results from those precepts in your own ruling faculty... ${ }^{30}$

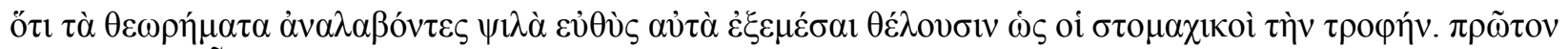

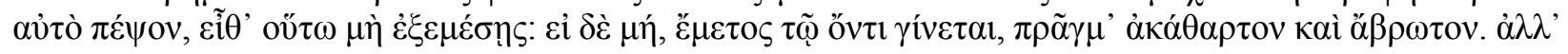

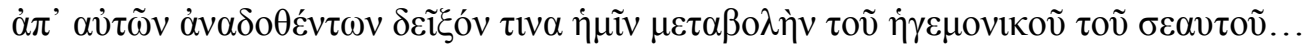

Once again, we see present the idea that it is digestion which allows philosophical principles $(\theta \varepsilon \omega \rho \eta ́ \mu \alpha \tau \alpha)$ to change our actions. In this passage this is made clear through the reference to a transformation of our ruling faculty or hegemonikon. Such a transformation is, after all, the goal of studying philosophy and the means of achieving virtue for a Stoic.

Introduced in this passage as well is the accompanying concept of vomiting. Digestion does more than render theory valuable. It is also what ensures that theory is not vomited and rendered unfit for us. Keeping with the metaphor, Epictetus warns us again that if theory is not digested, you will vomit it up:

So that if talk should arise amongst laymen on some philosophical principle ( $\theta \varepsilon \omega \rho \eta \dot{\mu} \mu \alpha$ ó $)$, remain, for the most part, silent; for there is considerable danger that you will immediately vomit up what you have not yet digested. And when someone tells you that you know nothing and you are not nettled by it, then you may be sure that you are setting to work at your task. For sheep do not bring their fodder to the shepherds to show much they have eaten, but digest their food internally, and produce wool and milk externally. And so you likewise should not display your principles to laymen, but rather show them the actions that result from these principles once they have been digested. ${ }^{31}$

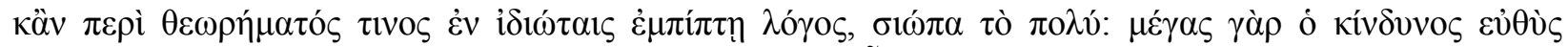

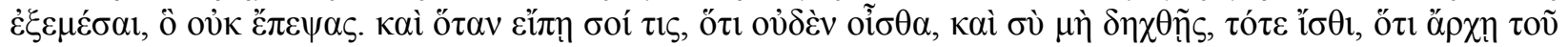

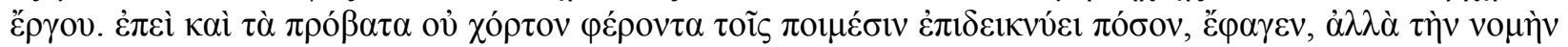

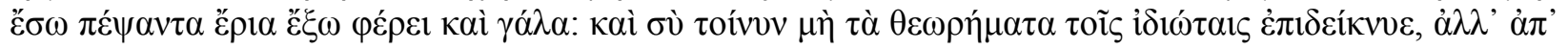

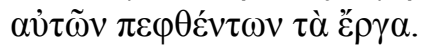

Epictetus holds that any philosophical principle not yet digested is at risk of being vomited by the individual. A picture of what vomiting exactly entails without a picture of what digestion

${ }^{29}$ Cf. I 4 6-17.

${ }^{30}$ Disc. III 21 1-3 trans. Hard.

${ }^{31}$ Ench, 46 trans. Hard. 
consists of is difficult to provide, but there are four things we can know about it at this point. First, is that it cannot coincide with digestion. Something that is vomited is not digested. Second, there is a performative or social aspect to vomiting. In the above passage Epictetus warns about discussing philosophy with others, for we risk vomiting up our principles. Additionally, when a student who does not live in accordance with Stoicism offers to read Epictetus his commentaries, Epictetus responds "Away with you! Look for someone else to vomit over". ${ }^{32}$ In this way, vomiting seems to be something we do with, or towards, other people.

Third, there is a personally harmful aspect to vomiting. This is emphasized in the following passage:

The first step, therefore, towards becoming a philosopher is to become aware of the true state of one's ruling faculty; for, when a person knows it to be in a weak state, he will not immediately employ it in great matters. But as it is, some, who can scarcely swallow a morsel, buy, and set themselves to eat, whole treatises; with the result that they vomit them up again, or suffer indigestion; and then come colics, fluxes and fevers. Such persons ought to consider what they can take. ${ }^{33}$

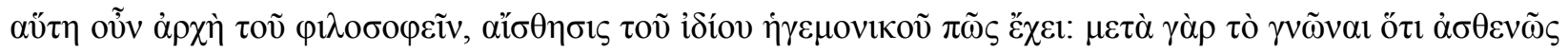

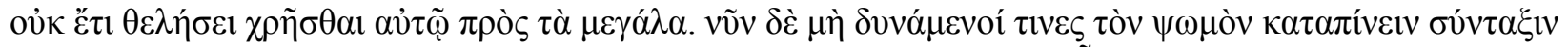

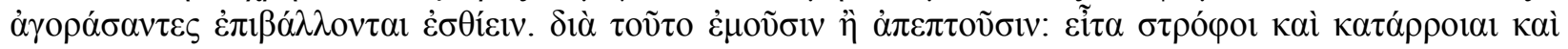

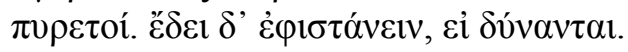

Staying faithful to his metaphor, Epictetus draws a connection between vomiting, indigestion and other physical ailments such as a fever. Thus not only do other not want to vomited upon, but the individual becomes sick themselves when they engage in this process. Finally, as evident from the above passage, vomiting, or a lack of digestion is associated with a lack of selfawareness, and an application of ourselves beyond our current level of progress.

Before we moved on to an account of what digestion entails, there are two additional points to be gained from the textual evidence. First, we have evidence that digestion entails something beyond theory. Epictetus warns that precepts learned as 'mere theory' shall be vomited and not properly digested. ${ }^{34}$ Digestion is prevented then when we limit our education exclusively to the study of theory. Thus, to ensure digestion we must add something above and beyond theory, but Epictetus does not explain in this passage what that additional factor could be. Returning to Book

\footnotetext{
${ }^{32}$ Disc. III 216 trans. Hard.

${ }^{33}$ Disc. I 26 15-17 trans. Hard.

${ }^{34}$ Disc. III 211.
} 
2, Chapter 9, we get our answer: digestion requires training. Just before Epictetus first mention of digestion, we are told that only proper acts of a virtuous nature can overcome the corrupting effects of vicious habits. And "for this reason philosophers exhort us not to be contented with mere learning, but to add practice also, and then training". ${ }^{35}$ This is strong evidence that there is an important link between training and the digestion of theory.

A final point about digestion to consider: the second quoted passage is taken from the

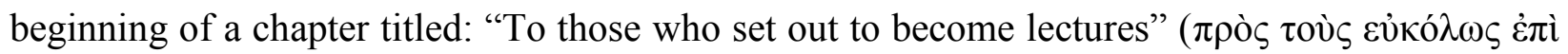

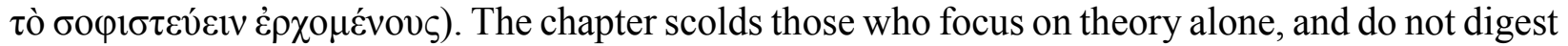
stoic precepts. As such, one major difference, if not perhaps the greatest difference in Epictetus' view, between a mere lecturer and a philosopher is that the lecturer neglects training, and focusing exclusively on theory. And if the connection between training and digestion I proposed is correct, then only philosophers actually practice digestion while lectures do not.

We are fortunate to have these passages, which provide information about digestion, its results, and the implications of neglecting it. Unfortunately for us, Epictetus does not provide an explicit account of the exact psychological function of digestion. We know that to have digested theory means the individual may act in accordance with it, but he does not tell us how digestion allows the individual to act in accordance with theory, or why digested precepts will not be vomited or rendered unfit for us. The next section will provide such an account. From these above passages we have learnt at least five features of digestion that any successful account must explain:

(1) The studying of theory is not sufficient for digestion to occur.

(2) Digestion concerns philosophical principles $(\theta \varepsilon \omega \rho \eta \dot{\mu} \mu \alpha \tau)$.

(3) Digestion stops the 'vomiting' of philosophical principles.

(4) Digestion allows philosophical principles to actualize their moral worth.

(5) A proper philosopher practices digestion, where-as those who set out to become lectures do not.

These features shall be our guide as we construct an account of the exact function and nature of digestion in Epictetus.

\footnotetext{
${ }^{35}$ Disc. II.9.13.
} 


\section{Pedagogical Function of Digestion}

\section{The Three Topoi}

Epictetus is unique amongst the few Stoics of which major writings remain, in that he was first and foremost a teacher. Unlike Chrysippus or Zeno before him, he was not primarily concerned with laying down a systematic explanation of the world. Unlike Marcus Aurelius, his Stoicism was not a personal means to help himself. Rather, Epictetus was committed to using Stoicism to transform the lives of his students. This is reflected in the form and function of the work of his which is preserved.

Our largest source of his work, the Discourses, is written by his prominent student, Arrian. The Discourses record and reconstruct informal lessons and conversations between Epictetus and his students, which were primarily young men from successful families who looked to Epictetus to prepare them for the complicated realities of business and political life at the time. Our other major source, the Encindrion or Handbook, also attributed to Arrian, distills these already informal lessons into an even simpler form. As the name Handbook implies, it would have been small enough to carry around during daily activities. This was so the central themes of Epictetus' teachings may be easily referred to and accessed at all times by students wishing to actualize their training outside of the classroom.

Central to the philosophy of Epictetus is a pedagogical approach. Thus the most effective method to understanding digestion is to try and place where it could fit within his pedagogical system. Epictetus divides education into a three parts. There are three areas of training, or topoi, one must master in order to act properly ${ }^{36}$ :

(1) Training oneself concerning desires and aversions.

(2) Training oneself concerning impulses.

(3) Training oneself concerning judgement and assent.

These areas must be practiced in the order listed as they build upon one another. For Epictetus, we may not effectively advance onto the next stages until we have mastered the previous one. $^{37}$

\footnotetext{
${ }^{36}$ Disc. III 2; I 17 22-4; 21 2; II 17 15-17 and 31-33; III 12 13-14; 26 14; cf. Cooper 2007, 15-19; Hadot 1998, 82-98; Long 2002, 112-118; Sharpe 2012, 381-383.

${ }^{37}$ Disc. II 17 10-17.
} 
It would be useful to examine these stages in greater detail. The first area concerns "desires and aversions, with the object of ensuring that a person does not fail in his desires or have experiences he does not want". ${ }^{38}$ So one's educational program properly begins with evaluating the value we place on external objects. By deeming them as either good or bad, we place value upon the wrong kinds of things: money, pretty women, social status etc. ${ }^{39}$ It is wrong to value these because they are external to us, and we are thus liable to suffer when our desires are frustrated. It is only when a person does not make these value judgements about external objects that one may never fail in his or her desires, and never suffer experiences they do not wish for themselves. ${ }^{40}$ This area of study was famously associated with physics by Hadot, because it entails coming to gain a proper understanding of what the world is. ${ }^{41}$ We are not then training ourselves to avoid attachment to external objects because they are painful to desire. Rather, they are painful to desire because they are not the proper objects of desire. Epictetus is compelling us to first, before anything else, gain a true understanding of the nature of the world, as it relates to our desires and aversions.

Once we have successfully refrained from desiring or fearing externals, then we may move towards the second area of study, concerning proper impulses, or how to successfully respect natural and acquired duties and obligations to others. The student should wish to be free from passion and perturbation, but they should also desire to know how to act properly in their lives. For as Epictetus says, "I should not be unfeeling like a statue, but should preserve my natural and acquired relations as a man who honors the gods, as a son, as a brother, as a father, as a citizen". ${ }^{42}$ It is not sufficient for the virtuous individual to be totally reclusive and introspective. We must still, as social animals that possess divine reason, respect the impulses that are natural and proper to us.

The progression here is apparent. If we do not master the first area of study, concerning desires and aversions, we will fail in the second, for these desires make us suffer from passions

\footnotetext{
${ }^{38}$ Disc. III 2 1, trans. Long 2002, 112

${ }^{39}$ Disc. III 2 8-9.

${ }^{40}$ Disc. III 23.

${ }^{41} 1998,91-93$.

${ }^{42}$ Disc. III 2 4, trans. Hard; cf. II 1731.
} 
and thus cause us to be unresponsive to reason. ${ }^{43}$ Only once we are free from passion may we use reason to determine which impulses are natural and thus permissible to follow.

At this point we are finally ready for the third area of study, concerning judgement. This area "falls to those who are already making progress and is concerned with the achievement of certainty in the matters already covered, so that even in dreams, or drunkenness, or melancholy no untested impression may catch us off guard." 44 Here Epictetus is in line with the orthodox view of the Stoic Sage as infallible, regardless of circumstances. At this stage, nothing new is introduced. The student is tasked instead with ensuring that they do not lose what they have already gained. This would be achieved by means of a thorough mastery of logic. ${ }^{45}$

Having given a brief overview of the three areas of study in Epictetus, the question is now where digestion should be understood to fit into this system. As noted above, digestion concerns principles or $\theta \varepsilon \omega \rho \eta ́ \mu \alpha \tau \alpha$. In Epictetus view, this is the domain of the first topoi. Enchridion 52 tells us that "The first and most necessary area of philosophy is the one that deals with the application of principles $(\theta \varepsilon \omega \rho \eta ́ \mu \alpha \tau \alpha)$ ". Thus there is a clear association between $\theta \varepsilon \omega ́ \rho \eta \mu \alpha$ and the first area of study. With this in mind, I will provide a position account of what I take the pedagogical function of digestion to be in Epictetus' educational program.

\section{Application of Preconceptions to Particulars}

Having concluded that digestion concerns the first area of study, let us examine it in greater detail. For Epictetus, the greatest problem facing those who wish to being practicing philosophy is the mistaken beliefs they have accumulated over their life time. It is for this reason that he states: "What is the first business of one who pursues philosophy? To cast away self-conceit". ${ }^{46}$ As adults, we cannot begin to study philosophy as blank slates. We carry with us a slew of misunderstandings about the world, accumulated through unique experiences, which impede our progress. It is these false judgements about the benefit or harm of externals that cause our passionate desires and aversions

\footnotetext{
${ }^{43}$ Disc. III 23.

${ }^{44}$ Disc. III 25 trans. Hard.

${ }^{45}$ Cf. Long 2002, 117.

${ }^{46}$ Disc. II 171 trans. Hard.
} 
If these misunderstandings were purely subjective and individualistic it would be difficult, perhaps even impossible, to convince individuals of the truth. However, an essential aspect to Epictetus' educational program is his belief that as rational beings we also possess universally shared, and correct, preconceptions. The cause of our misunderstandings, and the suffering that arises from them, is the misapplication of true preconceptions ${ }^{47}$ :

This is the cause of everyone's troubles, the inability to apply common preconceptions to particulars. Instead the opinions of men as to what is bad diverge. One thinks that he is unwell, when it's nothing of the kind; the problem is that he is not adapting preconceptions correctly. One imagines that he is poor, another that he has a difficult mother or father, still another that Caesar is not disposed in his favour. This is all caused by one and the same thing, namely, ignorance of how to apply one's preconceptions.

Who, after all, does not have a preconception of 'bad', to the effect that it is harmful, that it should be avoided, and that we should use every means to get rid of it? One preconception does not conflict with another, conflict arises when it comes to their application. What is this 'bad', then, which is also harmful and needs to be avoided? One says it's not being Caesar's friend: he's off the mark, he's not applying preconceptions properly... ${ }^{48}$

We see from this passage that Epictetus holds preconceptions to be common. Everyone grasps what it means for something to be harmful or bad for them. This understanding manifests itself motivationally. For the Stoics, recognition of value compels an impulse from the agent. So Epictetus defines these preconceptions in terms of how they will make us act. For something to be harmful means that 'it should be avoided' and that we should aim 'to get rid of it'. Humans differ not in their preconceptions, but in how they apply these preconceptions to particular things. Our false beliefs are categorization mistakes. One categorizes something that is indifferent, such as 'not being Caesar's friend', as harmful. This mistake in application then leads to an inability to control desires and aversions because we have placed value in an object of which we have no control.

By evoking preconceptions, Epictetus is following his Stoic predecessors. Preconceptions existed as a part of orthodox Stoic psychology. Preconceptions are developed through a natural tendency of the individual, qua rational agent, to assent to certain things are being true. ${ }^{49}$ In Early

\footnotetext{
${ }^{47}$ Cf. Disc. I 2 1-6; II 17.

${ }^{48}$ Disc. IV I 41-45 trans. Dobbin

${ }^{49}$ Cic. Acad. 2 30, Aetius 4 II 1-4 (SVF 2 83).
} 
Stoicism the individual would possess preconceptions of a variety of concepts, not just moral terms, some of which would be universal, some of which not. ${ }^{50}$

The major difference between Epictetus and his predecessors is that Epictetus focuses almost exclusively on moral preconceptions, which he believes to be universal without exception:

'Good', 'bad', 'useful', 'harmful' - these words are part of everyone's vocabulary, we all have a preconception of what they signify. But is it developed and complete? Prove it - apply it correctly to particular things. Now Plato, for his part, associates definitions with his preconception of what is 'useful'; you, however, categorize them as useless. Both of you cannot be right.... But why refer to conflict between different people, and bring up that? Just take yourself - if you are good at applying your preconceptions, why are you internally conflicted and confused? We will ignore for now the second field of study, to do with impulse and the art of applying impulse to appropriate acts. Let's skip the third field too, concerning assent - I'll give you a pass on both. Let's stay with the first; it furnishes almost tangible proof that you are not good at applying preconceptions. If your present desires are realistic - realistic for you personally why are you frustrated and unhappy? ${ }^{51}$

Epictetus is explicit that proper application of preconceptions is how to master the first area of study. We suffer from desires and aversions because we are poor at applying preconceptions to particular situations. It is also worth noting that the individual may not even be internally consistent with their application of preconceptions. It is unsurprising that what the layman student considers 'useful' differs with that of Plato, but that student also suffers from internal confusion, applying the same preconception to conflicting objects.

Up to this point we have seen that in order to master the first area of study, the individual must become adept at properly applying their preconceptions to particular situations. Given Epictetus' understanding of preconceptions as universal and true, it is clear now that the principles studied by students of Epictetus would not teach or alter their preconceptions. The principles would only help them to understand how to properly apply that preconception. Take the following examples:

Preconception $=$ I should pursue what is good.

\footnotetext{
${ }^{50}$ There is a controversy as to whether or not a preconception must be shared amongst men. For a good summary see Sandbach, 1971, 23-25, who argues that not all preconceptions are universally possessed. However even Sandbach agrees that Epictetus, contra to orthodox Stoicism, reserves the term preconceptions for specific moral terms (good, bad, the beautiful etc.), and describes them as being universally shared.
}

${ }^{51}$ Disc. II 2 10-17 trans Dobbin. 
$\Theta \varepsilon \dot{\rho} \rho \mu \alpha=$ Virtue is the only good. ${ }^{52}$

But preconceptions and philosophical principles alone do not yet get us to proper application. There is an additional step. There is a logical inference utilizing that $\theta \varepsilon \omega ́ \rho \eta \mu \alpha$ which allows us to properly categorize a specific object. In other words, believing that virtue is the only good does not immediately cause the individual to pursue only virtue. The individual must first examine the particular object, consider the definition of virtue, and successfully categorize the object as being an example of virtue, or not.

Epictetus explains this in the following passage. In this example, we mistakenly apply the preconception of god, that which 'has the capacity to confer most benefit', to politicians such as Caesar: "As a result we even honour them as gods, because we associate godhead with whatever has the capacity to confer most benefit. Then we posit a false minor premise: this man has the power to confer the most benefit. And the conclusion that follows from these premises is necessarily false as well", 53

The mistake here, as Epictetus makes clear, is not a lack of knowledge of philosophical principles as we might of assume, but rather a false the minor premise that Caesar has 'the power to confer most benefit'. The individual has failed to properly categorize and define the particular object 'Caesar'. In its most simple form, this mistake can be logically recreated as the following:

P1: I should honor as a god only that which confers the most benefit. (Preconception)

P2: Caesar has the power to confer the most benefit. (False premise)

$\mathrm{C}$ : I should honor Caesar as a god. (False conclusion)

They are a variety of reasons one might posit the false premise. It could be because the proper principle for this situation is not present because it has not been learnt yet, or it may be that the principle was not recalled or applied properly. To avoid this mistake, the individual must both possess the necessary principle and successfully apply the principle to the particular situation:

P1: I should honor as a god only that which confers the most good. (Preconception)

P2: Only reason has the power to confer the most benefit. $(\theta \varepsilon \omega ́ \rho \eta \mu \alpha)$

P3: Caesar is not reason. (Application of the precept to the particular situation)

C1: Caesar does not have the power to confer the most benefit.

C2: I should not honor Caesar as a good.

\footnotetext{
${ }^{52}$ Cf. Disc. 2915

${ }^{53}$ Epic. Disc. IV I 61 trans Dobbin.
} 
In the final example both P2 and P3 are necessary to arrive upon the correct conclusions. It should be evident now why Epictetus needs his students to study theory. Theory provides P2. Theory teaches students the philosophical which tell them how to properly apply their preconceptions in particular situations. But theory alone does not necessarily make the student aware of P3. The student must also take care to successfully apply the principle to the particular situation. Epictetus understood this well. This is part of the reason why Epictetus is so famously quick to criticize those who have a mastery of theory alone. ${ }^{54}$ One's knowledge of all the philosophical principles is useless if one does not use them to inform their beliefs about the particular situations they encounter. Such a student will be constantly internally conflicted. They will have memorized the works of Chrysippus but still fear of the judgement of others.

What a student requires then is some way to ensure that principles learnt in the classroom are successfully recalled and applied in the appropriate situations. But this cannot be the domain of theory, because theory takes the form of general principles. What are needed are strategies for learning concerned with particular situations. The student needs ways to help ensure he or she correctly applies their theory to specific contexts, and makes the correct categorizations. For Epictetus, we gain this skill through training. While it is beyond the scope of this paper to discuss the training exercises of Epictetus in detail, in recent work both Sellars (2007) and Braicovich (2012) discuss repetition as a necessary training exercise in the work of Epictetus. At multiple places in the Discourses, Epictetus demands that we train ourselves to constantly repeat and recall precepts situations in order to ensure that they are constantly mentally present and ready to be applied. ${ }^{55}$ As Sellars acknowledges, ${ }^{56}$ this two part focus on both theory and training was probably well known to Arrian as a student of Epictetus, who would have sought to reproduce it in his writings. The Discourses compliments theory, and contains philosophical principles and their detailed explanations. Where-as the Enchiridion compliments training, and is a list of simplified principles, which may be easily accessed when facing particular situations. Without both theory and training, the student would be unable to master desires and aversions, and could not progress to the second area of study.

\footnotetext{
${ }^{54}$ Cf. Disc. I 4 6-17.

${ }^{55}$ Cf. Disc. I 1 21-25; II 1 29-30; III 24 101-3, 115.

${ }^{56} 2007,136$
} 


\section{Digestion and Vomiting}

Finally we are ready to return to digestion. Given what has been discussed, it seems apparent that digestion is a metaphor for the process of transitioning from having merely learnt a principle as theory, to having successfully applied that principle in particular situations, such that one has formed beliefs about particular objects in accordance with that principle. So for example, when I do not value Caesar's opinion of me because I have made reference to my principles, I am beginning to digest those principles. I am beginning to render them valuable to me, they are beginning to change my ruling-faculty, and they will be manifested in my actions.

To have fully digested a principle then is to have removed internal contradiction and to have all the beliefs about specific objects in one's life be in accordance with that principle. The pedagogical function of digestion is that it allows us to master the first area of study. The way to master the first area of study, concerning desires and aversions, is to accumulate principles about the value of objects and then digest them. The student who has successfully done so will be ready to transition to the second area of study, for all of their beliefs concerning what is to be desired and avoided shall be correct.

But such a process of digestion does not occur naturally. It requires intentional training. We must be vigilant of the impressions we are assenting to, we must repeat principles to ourselves constantly and keep them accessible to us, and we must seek situations to test our level of progress. Thus digestion cannot be achieved by studying things as 'mere theory'. This sentiment is summarized well in the follow passage:

...Neither in wrestling, nor writing, nor reading, am I contended with mere learning: but whatever arguments are presented to me I twist in every direction, and I construct new arguments, and do likewise with arguments based on equivocal premises. But the necessary principles $(\theta \varepsilon \dot{\omega} \rho \eta \mu)$, but which I might escape from fear, grief, passion and hindrance, and be free, these I neither exercise $(\gamma v \mu v \alpha ́ \zeta \omega)$ myself in nor devote the appropriate care to. ${ }^{57}$

Epictetus says that we need to exercise ourselves in our principles. And if my reading of digestion is correct, then the reason this exercise is necessary should be clear. It is necessary to facilitate digestion.

\footnotetext{
${ }^{57}$ Disc. 46 15-16 trans. Hard.
} 
Vomiting and indigestion also play a significant role in Epictetus' account. It is beyond the realm of this paper to explore the concept in great detail, but I will attempt an interpretation given my account of digestion. Vomiting, in so far as we vomit our principles onto other people can be understood as espousing and advocating for principles we have not digested, and thus do not fully endorse. In other words, it is being a hypocrite, and not living in accordance with our principles. For example, attesting to Stoic theory to others, while simultaneously being nervous of what they think of us. This vomit is tainted matter unfit to eat because it demonstrates a shallow understanding of Stoicism. It does not benefit others, and it is a perversion of what may have been rendered useful to ourselves if it had been digested instead.

Indigestion, and the other problems that come from it, can be understood as the personal harm that comes from a lack of digestion. When we engage with the world with contradictory beliefs, we will experience conflict and confusion. The solution to both vomiting and indigestion then is to have our beliefs come into accordance with our principles, or in other words, digesting them. And this is achieved through training ourselves in our principles beyond the mere study of theory, and through being cautious to not take on more than our current level of progress allows. ${ }^{58}$

Let us return to the five features of digestion listed previously, and examine how this account can explain them:

(1) The studying of theory is not sufficient for digestion to occur.

As discussed above, theory is necessary to apply a principle to a specific situation, because it provides us with the principles, but it is not sufficient because it is too general to ensure successful application to a particular case with unique nuances. The individual may fail to recall the principle, or even if they do, they may make an incorrect inference, or fail to categorize an object properly. Thus the student must add training to their education, in the form of at least repetition and other exercises, in order to ensure that precepts are properly applied.

(2) Digestion concerns philosophical principles $(\theta \varepsilon \omega \rho \eta \dot{\mu} \mu \tau \alpha)$.

This account of digestion centers around philosophical principles, and locates itself within the first topoi, which is the area of study concerned with principles.

(3) Digestion stops the 'vomiting' of philosophical principles

We vomit principles and suffer indigestion when our particular beliefs do not align with the principles we assent to and recommend others to follow. This is to be cured then by having all of our beliefs align with our principles. When this is achieved we will no longer vomit nor suffer indigestion.

(4) Digestion allows philosophical principles to actualize their moral worth.

While philosophical principles are a necessary part of becoming virtuous, they are morally inert and without value unless one's understanding of them is reflected in his or her commanding faculty. ${ }^{59}$ Epictetus is not

${ }^{58}$ Disc. 126 15-17.

${ }^{59} \mathrm{Cf}$. III $211-3$. 
concerned with our ability to list what is to be desired and avoided. He is concerned with if we, in actuality, fail to achieve our desires or experience what we would rather avoid. ${ }^{60}$ By digesting principles, the student acquires correct beliefs about particular objects in the world, and this allows them to progress in terms of their actual desires and aversions.

(5) A proper philosopher practices digestion, where-as one who sets out to become a lecturer does not. The lecturer, by neglecting training and thus digestion, has memorized principles but cannot properly apply them to particular situations in their own lives. The lecturer may be able to cite Chrysippus and discuss aspects of virtue on a conceptual level, but they have neglected cultivating moral progress within themselves. In other words, the lecturer is concerned with theory alone and does not adopt philosophy as a way of life.

\section{Conclusion}

This paper has provided an interpretation of the metaphor of digestion in Epictetus. It has argued that digestion refers to the process by which students' beliefs about particular situations and objects become, through training, in accordance with the principles they have learnt as theory. It has argued that digestion fits within Epictetus pedagogy as a necessary component of his first area of study, that of mastering desires and aversions. As such, digestion is a necessary component of his overall educational program, and required to achieve virtue.

As a secondary goal, this paper hopes to have provided evidence that Epictetus did not believe digestion could be achieved through the study of theory alone. Rather, it seems a reason for introducing the metaphor at all was to call attention to how theory is insufficient for moral progress without training. It is my hope that a better understanding of the metaphor of digestion can help us to understand both that training was a necessary part of moral progress for Epictetus, and why training was necessary.

Michael Tremblay

${ }^{60}$ Cf. III 21. 


\section{Bibliography}

Braicovich, Rodrigo Sebastián. "Critical Assent, Intellectualism, and Repetition in Epictetus." Apeiron 45.4 (2012): n. pag. CrossRef. Web. 10 Apr. 2017. https://doi.org/10.1515/apeiron-2012-0004

Cooper, John M. "The Relevance of Moral Theory to Moral Improvement in Epictetus." The Philosophy of Epictetus. Ed. T. Scaltsas and Andrew S. Mason. Oxford: New York: Oxford University Press, 2007. 919. Print. https://doi.org/10.1093/acprof:oso/9780199233076.003.0002

Cooper, John M. Pursuits of Wisdom: Six Ways of Life in Ancient Philosophy from Socrates to Plotinus. Princeton University Press, 2012. https://doi.org/10.1515/9781400842322

Epictetus. Discourses and Selected Writings. Trans. Robert F Dobbin. London: Penguin, 2008. Print.

Epictetus. The Discourses of Epictetus. Trans. Robin Hard. London: Rutland, Vt: J.M. Dent: C.E. Tuttle, 1995. Print. Everyman Library.

Hadot, Pierre. Philosophy as a Way of Life: Spiritual Exercises from Socrates to Foucault. Trans. Arnold I. Davidson. Malden, MA: Blackwell, 1995. Print.

Hadot, Pierre. The Inner Citadel: the "Meditations" of Marcus Aurelius. Trans. Michael Chase. Cambridge, Mass.: Harvard University Press, 1998. Print.

Hadot, Pierre. What Is Ancient Philosophy? Cambridge, Mass: Harvard University Press, 2002. Print.

Johnson, Brian E. The Role Ethics of Epictetus: Stoicism in Ordinary Life. Lanham: Lexington Books, 2014. Print.

Long, A. A. Epictetus: A Stoic and Socratic Guide to Life. Oxford: Oxford: New York: Clarendon Press: Oxford University Press, 2002. Print.

Long, A. A., and D. N. Sedley. The Hellenistic Philosophers. Cambridge [Cambridgeshire]: New York: Cambridge University Press, 1987. Print. https://doi.org/10.1017/CBO9780511808050

Nussbaum, Martha Craven. The Therapy of Desire: Theory and Practice in Hellenistic Ethics. Princeton, N.J: Princeton University Press, 1994. Print.

Crivelli, Paulo. "Epictetus and Logic.” The Philosophy of Epictetus. Ed. T. Scaltsas and Andrew S.

Mason. Oxford; New York: Oxford University Press, 2007. 20-31. Print. https://doi.org/10.1093/ acprof:oso/9780199233076.003.0003

Sandbach, F.H. "Ennoia and Prolepsis in the Stoic Theory of Knowledge." Problems in Stoicism. Ed. A. A. Long. London: Athlone Press, 1971. 22-37. Print.

Scaltsas, T., and Andrew S. Mason, eds. The Philosophy of Epictetus. Oxford; New York: Oxford University Press, 2007. Print. https://doi.org/10.1093/acprof:oso/9780199233076.001.0001

Sellars, John. "Stoic Practical Philosophy in the Imperial Period." Bulletin of the Institute of Classical Studies 50.94P1 (2007): 115-140. CrossRef. Web. https://doi.org/10.1111/

j.2041-5370.2007.tb02420.x

Sellars, John. The Art of Living: The Stoics on the Nature and Function of Philosophy. Burlington, VT: Ashgate, 2004. Print. Ashgate New Critical Thinking in Philosophy.

Sharpe, Matthew. "It's Not the Chrysippus You Read: On Cooper, Hadot, Epictetus, and Stoicism as a Way of Life." Philosophy Today 58.3 (2014): 367-392. Print. https://doi.org/10.5840/philtoday20145225 